\title{
Гетероэпитаксиальные структуры InAIGaAs/InAlAs для электрооптического модулятора на основе квантово-размерного эффекта Штарка
}

Гуляев Д.В. ${ }^{1}$, Дмитриев Д.В. ${ }^{1}$, Торопов А.И. ${ }^{1}$, Валишева Н.А. ${ }^{1}$, Царев А.В. ${ }^{1,2}$, Колосовский Е.А. ${ }^{1}$, Федюхин Л.А. ${ }^{1}$, Горчаков А.В. ${ }^{2}$, Журавлев К.С. ${ }^{1,2}$

${ }^{1}$ ИФП СО РАН, 630090, Новосибирск, пр. Ак. Лаврентьева, 13

${ }^{2}$ Новосибирский государственньй университет, 630090, Новосибирск, ул. Пирогова, 2

DOI 10.34077/Semicond2019-442

В данной работе изучены свойства гетероэпитаксиальных структур (ГЭС) InAlGaAs/InAlAs на подложке InP для новой версии электрооптического модулятора на основе квантово-размерного эффекта Штарка. Особенностью предлагаемой конструкции модулятора является размещение слоя из нескольких InAlGaAs квантовых ям над толстым буферным слоем $\operatorname{In}_{0.52} \mathrm{Al}_{0.48} \mathrm{As}$ с показателем преломления, превышающим показатель преломления подложки InP. В этом случае слой множественных квантовых ям остается волноводным и в нем формируется основная оптическая мода с небольшим сечением. Оптическая мода во втором волноводе, сформированном из буферного слоя $\mathrm{In}_{0.52} \mathrm{Al}_{0.48} \mathrm{As}$, характеризуется гораздо большим поперечным сечением, что может обеспечить удобное соединение с оптическим волокном [1].

При выращивании гетероструктур методом молекулярно-лучевой эпитаксии были отработаны условия роста четырехкомпонентного твердого раствора InGaAlAs с кристаллической решеткой согласованной с (001) InP подложкой, и определены оптимальные условия роста для каждого слоя ГЭС. В результате были получены гетероструктуры с концентрацией дефектов на поверхности не более 500 на $\mathrm{cm}^{2}$, что достаточно для создания на их основе интегрированных оптических модуляторов.

Методом фотолюминесценции изучено влияние состава и толщины слоев множественных квантовых ям $\mathrm{In}_{0.53} \mathrm{Ga}_{0.47 \mathrm{X}} \mathrm{Al}_{0.47(1-\mathrm{x})} \mathrm{As} / \mathrm{In}_{0.52} \mathrm{Al}_{0.48} \mathrm{As}$ на величину эффекта Штарка (см. рис. 1). Величина электрооптического эффекта, определенная из изменения коэффициента отражения рполяризованного излучения вблизи угла Брюстера на рабочей длине волны модулятора 1.55 мкм, составила для напряжения в 2-3 Вольт порядка $\Delta \mathrm{n} \sim 0.01$ в исследованных ГЭС. Такой электрооптический эффект вполне достаточен для реализации на основе InGaAlAs ГЭС модулятора МахаЦендера. Помимо этого, для всех слоев ГЭС, различающихся составом и уровнем легирования установлены вещественная

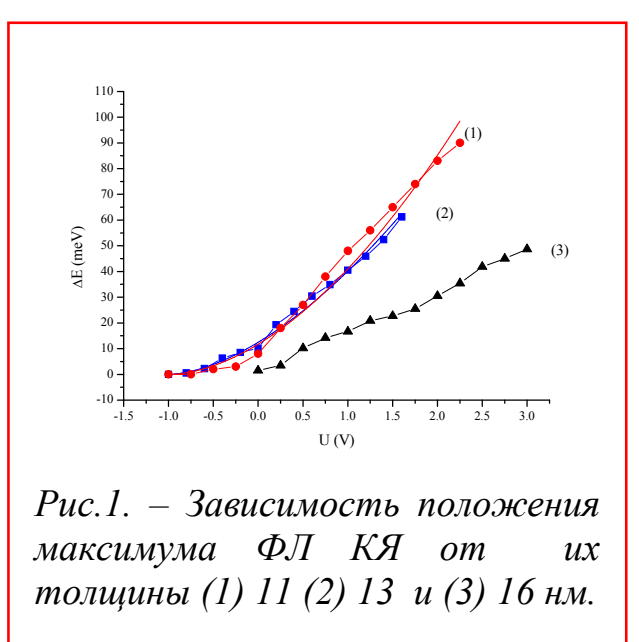
и мнимая часть коэффициента преломления. Проведено сравнение полученных данных с данными моделирования и выбрана оптимальная конструкция структуры для создания на ее основе оптического модулятора InP.

Полученные ГЭС использованы для отработки и изучения особенностей технологии изготовления оптического модулятора с применением разработанных режимов формирования волновода (в разрядной плазме в $\mathrm{BCl3}$ ), планаризации поверхности и металлизации омических контактов с соответствующими слоями ГЭС на основе композиций $\mathrm{Ge} / \mathrm{Au} / \mathrm{Ni} / \mathrm{Au}$ и $\mathrm{Ti} / \mathrm{Au}$.

[1] А.В. Царев, Р.М. Тазиев, Квантовая электроника, 49:3, 266 (2019) 